\title{
WEAK AND SEMIWEAK PHONOLOGICAL POSITIONS IN ENGLISH*
}

\author{
Katalin Balogné Bérces \\ Pázmány Péter Catbolic University, Piliscsaba, Hungary
}

\begin{abstract}
The paper argues that, besides the distinction between strong and weak phonological positions, a further dichotomy of weak and semiweak positions is justified in English, manifesting itself in consonant lenition as well as vowel reduction and syncope. Namely, a consonant/vowel immediately following the metrical head is more prone to lenite/reduce than a later consonant/vowel. An extensive discussion of the relevant data, taken from t-allophony and vowel reduction, as well as the introduction of the novel results of an investigation of schwa syncope in British English are provided. The analysis is set in a subbranch of Government Phonology called Strict CV (or CVCV) phonology, in which a licensed position is strong, a governed position is weak, and one which is both licensed and governed is semiweak. It is also shown that previous accounts of some of the data, making reference to foot adjunction structure, handle the observed facts inadequately either because they are unable to predict the observed patterning of strong vs. semiweak realisations, or because they allow for reduction where it is not on record.
\end{abstract}

Keywords: English phonology, lenition, vowel reduction, syncope, Government Phonology, CVCV phonology.

\footnotetext{
The very first draft of the paper was presented at the First International Conference on the Linguistics of Contemporary English (ICLCE1) in Edinburgh on 23-26 June 2005. I am grateful to the audience there, as well as to Miklós Törkenczy, Péter Szigetvári, Szilárd Szentgyörgyi and two anonymous reviewers, for their comments on various later versions.

* Correspondence should be sent to: Katalin Balogné Bérces. Institute of English, Pázmány Péter Catholic University, Piliscsaba, Hungary. Egyetem u. 1., Piliscsaba, H-2087, Hungary. Email: bbkati@ yahoo.com
} 


\title{
POSICIONES FONOLÓGICAS DÉBILES Y SEMI-DÉBILES EN INGLÉS
}

\begin{abstract}
RESUMEN. Este artículo sostiene que, además de la distinción entre las posiciones fonológicas fuertes y débiles, es posible establecer una categorización adicional entre las posiciones débiles y semi-débiles en inglés, que se manifiesta en un debilitamiento de la consonante, así como en una reducción vocálica y síncopa. En concreto, una consonante/vocal que aparezca inmediatamente después al núcleo métrico está más sujeta al debilitamiento que una consonante/vocal posterior. En este trabajo se exponen los datos más relevantes de manera detallada, extraídos de la alofonía de la ty la reducción vocálica, a la vez que presentan nuevos resultados obtenidos de la investigación de la síncopa de la schwa en inglés británico. El análisis se realiza dentro de en una sub-rama de la Fonología de Rección llamada Strict CV (o CVCV) Phonology, en la que una posición intrinseca es fuerte, una posición sujeta a rección es débil, y una que es tanto intrínseca como sujeta a rección es semi-débil. También se demuestra que investigaciones anteriores sobre algunos de los datos que aqui se presentan, y que hacen referencia a la estructura de adición a la base, dan cuenta de los hechos observados inadecuadamente, ya sea porque el análisis no predice los patrones de realizaciones fuertes vs. semi-débiles observados, o porque permite la reducción donde no ha sido registrada.
\end{abstract}

Palabras clave: Fonología inglesa, debilitamiento, reducción vocálica, síncopa, Fonología de Rección, Fonología CVCV.

Received 01 May 2010

Revised version accepted 20 January 2011

\section{INTRODUCTION AND THEORETICAL BACKGROUND}

\subsection{INTRODUCTION}

In English, the phoneme /t/ undergoes a wide range of processes under various conditions in all the native accents. For example, in most dialects it exhibits some degree of aspiration word-initially and before a stressed vowel (i.e., in foot-initial position, e.g., Tom, atómic $\left[\mathrm{t}^{\mathrm{h}}\right]$ ), traditionally analysed as fortition or strengthening, whereas it typically weakens or lenites in, e.g., foot-internal intervocalic and wordfinal positions. This process of lenition may manifest itself in various forms across speakers, registers, styles and accents, from a simple reduction of the degree of aspiration to (pre)glottalisation (e.g., but, cat $\underline{\underline{t}}\left[{ }^{2} \mathrm{t}\right]$ ) or the full replacement of the /t/ with a tap or flap (e.g., átom, city [r] in the so-called tapping dialects like most forms of North American English), the glottal plosive (called glottalling, e.g., átom, city [?] in London English), a coronal or glottal fricative (e.g., cíty [s] or cat [h] in parts of the North of England), or even zero (e.g., but in forms of Irish English). Consequently, the foot-initial position is frequently characterised as phonologically strong, while those favouring lenition phenomena are phonologically weak. The 
present paper argues that a further division of the latter case into two subtypes, weak (proper) and semiweak is necessary for the appropriate description of the observed facts.

Many have noticed (e.g., Withgott 1982, Jensen 1987, Harris and Kaye 1990, Burzio 1994, Steriade 2000, Jensen 2000, Davis 2003, 2005, just to mention a few) that in English (word-internal) dactylic sequences the unstressed position immediately following the foothead is more prone to reduce than the next syllable. For instance, in capácity or éditor aspiration is more acceptable than in átom or glitter (e.g., Kahn 1976: 165 fn.17, Hooper 1978, Selkirk 1982, Kenstowicz 1994: 69, Kreidler 1989: 110-111, Vaux 2002 and references therein). Harris and Kaye (1990: 261) also note that in words with two successive potential lenition sites, e.g. compétitive, the second is less prone to glottalize or tap than the first. Sections 3.1 and 3.2 below provide an extensive discussion of the relevant data.

In addition, as observed by Withgott (1982) and Jensen (1987), taps may be suppressed in certain positions, e.g., the underlined t's tend to be aspirated rather than flapped in milițarístic, sànițisátion, mònotonícity, Mèdițerránean, Wînnipesáukee, Nàuratilóva, àbracadábra, etc. They are contained in the third syllable of wordinternal dactylic sequences, i.e., between the other unstressed syllable of their ternary foot to the left and the stressed syllable of the next foot to the right. This systematic absence of lenition in American English in the third position of nonfinal dactyls has been dubbed the Withgott-effect, and in morphologically derived words like militaristic it is allegedly caused by the absence of lenition in the base militàry as a result of Paradigm Uniformity (PU) (Steriade 2000).

Although Davis (2003, 2005) claims that tap suppression only takes place in non-final dactyls and final dactyls like sánity are excluded from its scope, I will argue below that there is no significant asymmetry between final and nonfinal dactylic sequences. My suggestion, then, is that a distinction can be drawn between the 'weak' position immediately following the head of the foot and a 'semiweak' position following it, irrespective of where in the word the sequence is situated. I base this claim on evidence coming from various sources of the fact that, although in final semiweak positions the frequency of tapping is somewhat higher and VOT in case of aspiration is shorter, flapping does not apply in such a uniform fashion as in the preceding weak positions: word frequency and speech style can exert their influence there, much the same way as word-medially.

Vowel reduction, i.e., the weakening of vowels under zero stress, appears to exhibit the same pattern. It is Burzio (1994: 113, footnote 14) who first pointed out that in English, foot-medial open syllables are affected by reduction to a greater extent than foot-final syllables. In the total reduction of a vowel from schwa to zero, i.e., in cases of deletion or syncope, too, a stronger tendency is attested for a first schwa to syncopate (e.g. functionary in the British English pronunciation) 
than for a second one (e.g. fúnctionary). Section 4 below introduces the results of an investigation of such data.

The present paper proposes to relate all these (apparently disparate) phenomena to a general distinction between weak and semiweak positions, originally introduced for Dutch in e.g. van Oostendorp (2000): the first unstressed position is weak, the second is semiweak. I argue, against Davis (2003), that there is no asymmetry between the behaviour of word-internal and final dactyls: the same strong-weak-semiweak pattern is detectable in both militarístic/Nàvratilóva and compétitive/vánity. In addition, pretonic unstressed syllables do not exhibit the same degree of phonological strength/weakness: word-initially they are generally stronger (as in potáto, with almost as much aspiration on the $/ \mathrm{p} /$ as on the first /t/) than medially (as in Winnepesáukee). Therefore, foot-based adjunction analyses, propagated in Withgott (1982), Jensen (1987, 2000), Davis (2003), etc. are inadequate either because they predict the same amount of aspiration in Winnepesáukee as in potáto, or because they allow for a reduced vowel in a monosyllabic foot. Moreover, given the symmetrical behaviour of militarístic and vánity, it is desirable that the two receive the same treatment, but the mechanism adjoining the third syllable of the dactyl to the right is clearly unavailable in vánity.

The paper is structured as follows. After the theoretical background is sketched out in Section 1.2, Section 2 introduces the concept of weak and semiweak positons in Dutch. Sections 3 and 4 argue for the relevance of the same distinction in English, with examples from t-lenition (Sections 3.1, 3.2) including the 'Withgott-effect' (Section 3.3) and from vowel reduction and schwa-syncope (Section 4). Then Section 5 provides the CVCV analysis, and Section 6 concludes the discussion.

\subsection{THEORETICAL BACKGROUND}

The analysis is couched within the theoretical framework called Strict CV (or CVCV) phonology (Lowenstamm 1996, Scheer 2004, etc.), a branch of Government Phonology (GP - Kaye et al. 1985, 1990, etc.), introducing a new type of phonological skeletal structure, in which syllabic constituency and timing are merged into a skeletal tier consisting of strictly alternating $\mathrm{C}$ and $\mathrm{V}$ positions, and parametric variation in syllable structure is expressed with reference to the licensing of empty positions rather than branching. A ,closed syllable', then, will have its final consonant followed by an empty nucleus (the morpheme-final version of which is dubbed Final Empty Nucleus (FEN) - cf. (1a)), while consonant clusters including geminates (1b) and vocalic sequences including long vowels (1c) will be composed of two C slots and two V slots, respectively, sandwiching an empty position each. 
a. closed syllable

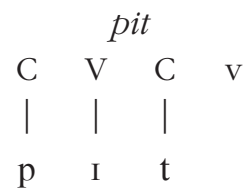

b. geminate Italian dottore 'doctor'

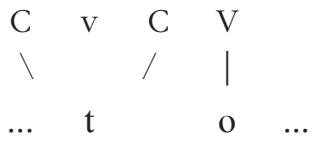

c. long vowel pea

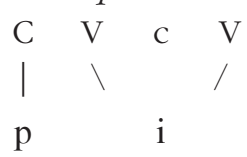

Empty positions, however, are not allowed in languages to proliferate freely. Crucially to our present discussion, a parameter circumscribes the presence of final empty nuclei (FENs) in languages: the ON setting (as in English, cf. (2) below) allows for (phonetic) consonant-final words in the language, the OFF setting, on the other hand, implies the absence of such words (as in Italian or Japanese). The other force which is able to silence v's is called Proper Government (PG). Via PG, a nonempty nuclear position licenses an empty one adjacent on the nuclear projection. The direction of PG is assumed to be governed by a parameter, but all reported cases illustrate the iambic type. Cf. (2).

(2) English butler

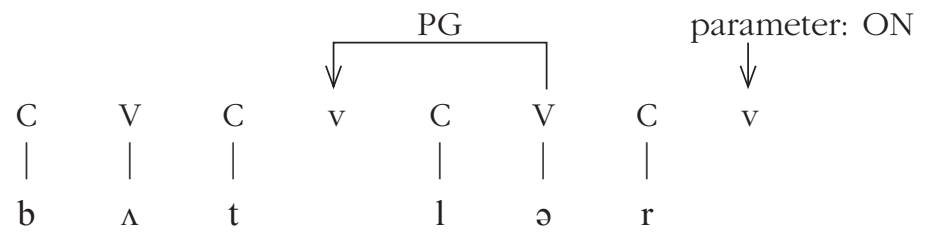

Proper Government is not only operative word-internally, but its other key function is to take care of the left edge of words. Lowenstamm (1999) proposes to represent the beginning of the word, traditionally denoted by \#, as an empty $\mathrm{cv}$ span (called the boundary marker). (3) below is the version of (2) amended accordingly.

(3) English butler

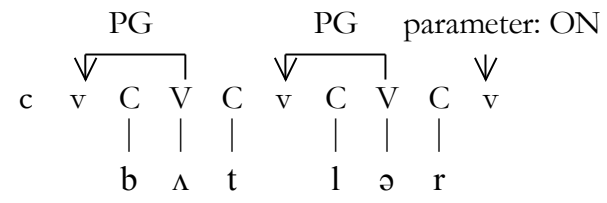

\footnotetext{
1 I am adopting Szigetvári's (e.g., 1999) notation, which uses upper-case letters for non-empty positions, and lower-case letters for empty ones.
} 
Besides government, segments also contract another lateral relationship called licensing. In (4), I list the major theoretical assumptions concerning the two forces.

(4)

a. Vocalicness is loud, not only acoustically but also in the sense that V slots in the phonological skeleton aim at being pronounced. (Szigetvári 1999: 62)

b. Consonantalness is mute, if nothing intervenes a $\mathrm{C}$ position will stay silent. (Szigetvári 1999: 62)

c. Government spoils the inherent properties of its target. (Szigetvári 1999: 66)

d. Licensing comforts segmental expression of its target. (Ségéral and Scheer 1999: 20)

e. Stressed vowels are unable to govern into non-peripheral units.

f. The government whereby a vowel affects a preceding consonant operates on the melodic level.

It follows from (4a-d) that a licensed C finds itself in a phonologically strong position, while C's which are governed and C's which are neither governed nor licensed are expected to lenite. (4e) is responsible for the lack of weakening (in English at least) before stressed vowels, i.e., foot-initially, and (4f) ultimately derives cross-word cases of lenition, irrelevant to the present topic. To translate this to describe the facts of t-lenition introduced above, a / t/ is aspirated in a phonologically strong position, viz. when licensed but ungoverned; this situation emerges before stressed vowels (since, in accordance with (4e), they are unable to govern into a preceding CV slot, e.g., atómic, cf. (6b) below) and wordinitially (when the vowel's governing potential is used up by the requirement to silence the empty $\mathrm{v}$ in the boundary marker, e.g., Tom - cf. (3) above and (5) below). There are two types of phonologically weak positions, one is before an empty $\mathrm{v}$, which is roughly before a consonant and word-finally - in such cases consonants remain ungoverned and unlicensed and exhibit 'consonantal' lenition (they devoice, deaspirate, debuccalize, etc.), i.e. t's are (pre)glottalised, cf. butler in (3). The other weak position is that of foot-internal intervocalic C's, which receive both government and licensing from the following (unstressed) vowel; here consonants tend to move towards vocalicness (they become more sonorous), e.g. t's are flapped, as in atómic, cf. (6a) below.

The representations in (5)-(6) below illustrate the relevant cases. The absence of word-initial lenition stems from the fact that the boundary marker is present and requires silencing: the first nonempty $\mathrm{C}$ of the word is licensed only (indicated by ' $\Leftarrow$ ' - cf. (5)). Before stressed vowels within words, the /t/ escapes government 
again since (4e) is operative: a word-internal CV unit is non-peripheral (6b). Lenition by government, usually manifesting itself as tapping/flapping, is predicted to occur before unstressed vowels word-medially (6a).

(5) Tom

$$
\begin{array}{cccc}
\underset{\mathrm{v}}{\mathrm{V}} & \mathrm{C} \in \mathrm{V} & \mathrm{C} & \mathrm{v} \\
\mid & \mid & \mid \\
\mathrm{t} & \mathrm{d} & \mathrm{m}
\end{array}
$$

(6)
a. átom
b. atómic
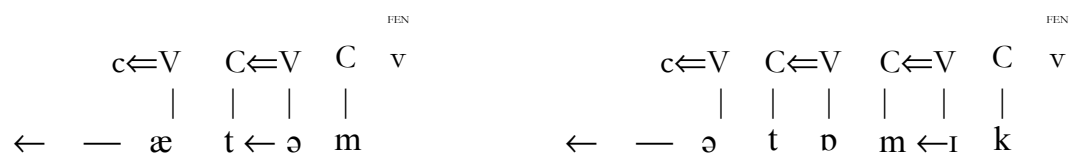

I claim that, based on Ségéral and Scheer's (1999) and Szigetvári's (1999) definitions of government and licensing as two antagonistic forces (4c-d), the theoretical framework just sketched out is capable of expressing the relative weakness of the weak position of the dactyl, rather than the relative strength of the semiweak position. This way, it accounts for all the observations enumerated above without making reference to foot structure.

\section{WEAK VS. SEMIWEAK POSITIONS}

The distinction between weak and semiweak phonological positions was introduced for Dutch by van Oostendorp (2000 147-148) to describe the propensity full vowels exhibit to alternate with schwa in stressless positions (basically, in free variation, the difference between reduced and unreduced pronunciations being one in style registers). What the Dutch data show is there are two types of unstressed position: one which is more prone to reduce ('weak') and another with less frequent reduction ('semiweak'). This is illustrated by the possible pronunciations of the Dutch word for 'phonology'.

(7) fonologie 'phonology'

very formal: [, fonolo'yi]

less formal: [,fonəlo'yi]

even less formal: [,fonələ'yi]

but: * [,fonolə'yi] 
The conclusion to be drawn is that the syllable -lo- is more resistant to reduction: it is in semiweak position. The usual analysis of this absence of reduction in the final syllables of word-internal dactyls makes reference to foot structure, as shown in $(8)^{2}$. Since feet are maximally binary, -lo-remains unfooted unless it erects a foot itself. As a result, both $f_{O}$ - and -lo- are footheads, and are therefore expected to be strong, as opposed to -no-, which forms the recessive position of the first foot. The two metrically prominent syllables (fo- and -gie) are different from $-l^{-}$, however, since they are heads of superfeet ( $\Sigma$ =superfoot).

(8)

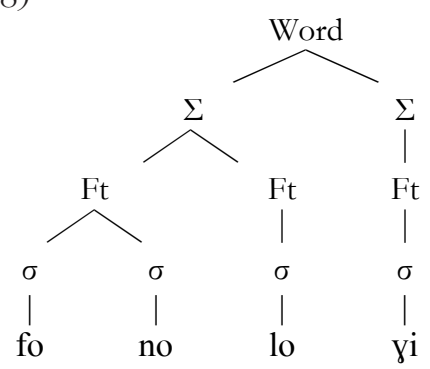

In van Oostendorp's OT account, two separate constraints are proposed relating to footheads: one ensures that no reduction takes place in heads of feet ( $f_{O}$ - and -lo-), the other bans reduction in heads of branching feet (and applies to fo- only). While [,fonolo'yi] and [,fonəlo'yi] do not violate either, and [,fonələ'yi] violates the first one only, the unattested *[,fonolə'yi] would both violate the first constraint and contain an unreduced vowel in a non-foothead position.

\section{WEAK AND SEMIWEAK POSITIONS IN LENITION IN ENGLISH}

\subsection{TAPPING AND GLOTTALLING DATA IN HARRIS AND KAYE (1990)}

In their survey and GP analysis of t-lenition in New York City (NYC) English (tapping) and London English (glottalling), Harris and Kaye (1990: 261) note the remarkable behaviour of words with two successive potential lenition sites, e.g. compétitive. Here, two t's are followed by an unstressed vowel each, therefore both are expected to lenite. However, as Harris and Kaye observe, the second /t/ can only undergo weakening if the first one does so, too. This is illustrated for London glottalling in (9), but corresponding results are reported for tapping in NYC.

2 (8) is a reproduction of Figure (17) in van Oostendorp (2000: 148). 
(9) compétitive

compe[t]i[t]ive

compe[?]i[t]ive

compe[?]i[?]ive

*compe[t]i[?]ive

Notice the parallelism between (7) and (9). Harris and Kaye are at a loss how to interpret this "'chain' of reduction". They provide a non-CVCV GP account of NYC English tapping and London glottalling, in which lenition affects consonants trapped between two vowels contracting what they take to be a licensing relationship emanating from the foothead and targeting other vowels within the same foot. In this respect, there is no difference between the two t's, as illustrated in (10): $N_{1}$, the stressed vowel, licenses both $N_{2}$ (sandwiching $\alpha$ ), as shown by the shorter arrow, and $\mathrm{N}_{3}$ (sandwiching $\beta$ ), as shown by the longer arrow. In fact, they use this as the motivation for lenition in both political and sánity.

(10)

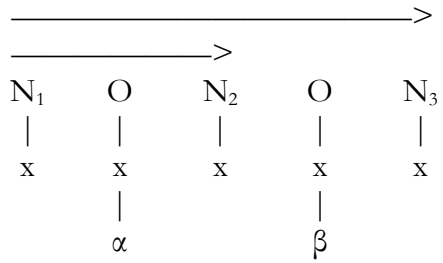

However, the data can be reinterpreted as another manifestation of the weak vs. semiweak distinction: there is a stronger tendency to lenite in the weak position (compétitive), whereas the semiweak position (compétitive) is more resistant to reduction. ${ }^{3}$

\subsection{DIFFERENCE BETWEEN POST-TONIC AND LATER POSITIONS}

There is ample evidence that even in cases when only one lenition target is available, the behaviour of the immediate post-tonic consonant and that of the following position are asymmetrical. Several speakers of American English have reported that $\mathrm{a} / \mathrm{t} / \mathrm{immediately}$ following the stressed vowel (e.g. Ítaly) must be a flap, a later /t/ (e.g. sánity) may be a flap. Hooper (1978), for example, claims that only post-tonic consonants are ambisyllabic, which is reflected by the fact that only such t's are flapped (as in kitty) as opposed to intervocalic consonants not

\footnotetext{
3 Notice that this statement goes straight against Szigetvári's (1999: 47), which asserts that "in a word like competitive the two t's are subject to the same type and degree of lenition".
} 
preceded by the stressed vowel (as in serénity, which contains an aspirated / $\mathrm{t}$ / for Hooper). As we have mentioned above, a number of authors find aspiration in words like capácițy or édițor more acceptable than in words like átom or glitter (e.g. Selkirk 1982, Kreidler 1989: 110-111, Kenstowicz 1994: 69, Vaux 2002 and references therein). To quote Kahn (1976: 165 fn.17): "In some words which appear to be entirely on a par structurally with words like capital, failure to tap is not quite serious an affront to the American ear as the absence of flap usually is. Compare better, capital with marital. Even in the case of the latter word, however, /D/ is preferred greatly", whereas "[in immediate post-tonic position] as in better, unflapped / $\mathrm{t} /$ is unnatural even in very careful speech" (ibid: 94). In a phonetic study, Patterson and Connine (2001), when listing the six possible phonetic environments of a medial /t/, only consider the immediate post-tonic position as the 'flap environment', as in wáter, párty, and list the intervocalic unstressed position (as in párity) under a separate heading, excluding it from the focus of their study. Vaux (2002) observes the difference between consérvative (with flapping) and sédative (without) - whatever causes this variation, it clearly affects the second unstressed position after the tonic.

I conclude that for these speakers (and authors), this is a difference between weak and semiweak positions: the later /t/ is in semiweak position, and as such is more resistant to reduction.

\subsection{THE 'WITHGOTT-EFFECT'}

Withgott (1982) was the first to highlight and analyse tap suppression in certain positions. She recorded that the /t/ is flapped in càpitalistic, as expected, but aspirated in militarístic, sànitisátion, mònotonícity. She pointed out that while capitalistic is morphologically related to capital, where the /t/ is already flapped, the untapped t's are all found in a derivative where there must be an untapped $/ \mathrm{t} /$ in the base due to stress on the syllable whose onset the /t/ is (militàry, sánitize, mónotòne). She also argued that a cyclic analysis (i.e., one relying on the morphological complexity of these words) is not appropriate since aspiration (instead of lenition) is attested in words like Méditerránean, Winnipesáukee, Nàvratilóva, àbraçadábra, which are morphologically independent. She proposed an adjunction analysis: stray syllables always attach to adjacent feet. Accordingly, po- in potáto adjoins to the right while in words like àbracadábra, after the localization of footheads, there remain two stray syllables inbetween; the first is adjoined to the left, while the second adjoins to the right. In this way, the second unstressed syllable following the stress becomes foot-initial, therefore strong. This is a modification of Hayes (1982), where both stray syllables are assumed to adjoin to the left. 
Jensen (1987) pursues the same idea as Withgott ${ }^{4}$. He brings supporting arguments from native intuition (informants were asked to divide words like àbracadábra into two parts), and verifies the results with instrumental measurements of the duration of stop release in the same words, only to underpin Withgott's intuitions. He concludes that the third syllables of such words are footheads, since only foot-initial voiceless plosives are aspirated. The stray syllable adjunction rules he assumes are explicitly formulated in Jensen (2000: 210), where he derives the difference between càpitalístic and militarístic in terms of a cyclic derivation of stress and foot structure. In the first cycle in capitalistic, the only possibility is for (capital) to be assigned a dactylic foot (enclosed in the parentheses), which is preserved in the second cycle, yielding (capita)(listic). In both instances the $/ \mathrm{t} / \mathrm{is}$ foot-internal. In military, however, two feet are produced in the first cycle ( $($ mili $)$ $($ tary)). In the second cycle, the foot (ristic) is formed on the right and stray -taadjoins to the right, giving (mili)(ta(ristic)).

Although it has the same effect, Withgott's and Jensen's solution is just the opposite of van Oostendorp's in (8) above.

Steriade (2000: 322-326) also addresses the problem, though she approaches it from a completely different angle. She claims that Paradigm Uniformity (PU) is at work here. PU promotes the invariance of some sound property within a paradigm, and is defined as given in (11).

(11) Paradigm Uniformity

All surface realizations of $\mu$, where $\mu$ is the morpheme shared by the members of paradigm $\mathrm{x}$, must have identical values for property $\mathrm{P}$. (Steriade 2000: 313)

Tap suppression in words like militaristic is a PU effect, Steriade claims: it is the paradigmatic extension of the unflapped stop of military, more precisely, of the [extra-short closure] feature the flap does, but the stop does not, possess. To show that the Withgott-effect is systematic, Steriade presents the results of a survey she carried out with 12 speakers of American English, who were asked to read out the following (often nonce) words.

(12) a. Bases: positive, primitive, relative, negative, voluntary

Derivatives: positivistic, primitivistic, relativistic, negativistic, voluntaristic

b. Bases: rotary, fatal, fetish, totem, notary

Derivatives: rotaristic, fatalistic, fetishistic, totemistic, notaristic

\footnotetext{
${ }^{4}$ He does not refer to Withgott, though.
} 
Derivatives in -istic are expected to display stem invariance effects since the morphological operation producing them is highly productive, and they are (fully) compositional. In the bases in (12a), speakers differ as to whether -ive and-ary are stressed - consequently, whether the /t/ can be flapped. The quality of the /t/ in the bases is predicted to determine the one in the derivatives. In the words in (12b), however, all intervocalic t's should be tapped, being followed by stressless vowels. In the survey the words in (12a) were mingled with the words in (12b) to minimize the influence of similar words on each other, and also to check whether the informants were not producing artificially untapped pronunciations. The results showed virtually no exceptions to base-derivative correspondence, i.e., whenever there was a tap in the base in the examples in (12a), there was a tap in the derivative, and whenever there was an untapped / $t /$ in the base, it was unchanged in the derivative.

In monomorphemic strings PU is irrelevant, and, as Steriade observes, t's are generally tapped in unstressed position in words like mèritocrátic, hèmatogénesis, pèritonitis, bèmatocýstic. She insists that Mèditerránean is a unique underived form in which the tap is suppressed; her explanation is that the orthographic geminate $<\mathrm{rr}>$ is interpreted by speakers as an indication of secondary stress on the preceding vowel. Unfortunately Steriade does not comment on Withgott's other examples, which do not contain orthographic geminates in the relevant position at all (cf. Wînnipesáukee, Nàvratilóva, àbracadábra). Vaux (2002) adds Vînatiéri to the list, and cites lollapalóoza from Davis (2001). Among others, Jensen (2000) and Davis $(2003,2005)$ insist that this reflects a regular pattern, which goes against Steriade's analysis.

What is of really high relevance to the present discussion, however, is what Steriade remarks in her endnote 4: tap suppression does not obtain in syllables that directly follow the tonic, as in word pairs like statístic - stàtistícian; in the second item in these pairs a tap usually appears and, generally, there are very few instances of non-tapped $\underline{\mathrm{t}} \mathrm{s}$ in the V_v context: "[...] constraints that induce tapping are more stringent (i.e. more highly ranked) in the immediate post-stress position than elsewhere. PU effects surface only when the tapping constraint is weaker." (Steriade 2000: endnote 4.) In light of the foregoing discussion, this remark can be interpreted to argue that examples of tap suppression (whether or not they are manifestations of PU effects) are only found in the semiweak position, irrespective of morphological structure.

Davis (2003) claims that there is an asymmetry between final and nonfinal dactylic sequences. Based on data from flapping, aspiration and expletive infixation, Davis finds that only nonfinal dactyls contain a strong third syllable. He ignores the variation described above and states that in words like cápital, serendipity, chárity the /t/ is "clearly flapped" (ibid: 278). He also cites Van Dam and Weaver 
(2001), who show that the voiceless stops /p/ and $/ \mathrm{k} /$ at the beginning of the final syllable of words like América, Connécticut, Oédipus are lightly aspirated and have neither the degree of aspiration that accompanies a foot-initial voiceless stop nor the aspiration that is attested in nonfinal dactyls like Mèditerránean. He concludes that this is due to the fact that the stops in words of the cápital and América type are foot-internal.

In contrast, in nonfinal dactylic sequences the third syllable is adjoined to the right, and therefore it is not foot-internal but foot-initial (in the same way as in Withgott 1982 and Jensen 2000). He argues that both Jensen (2000) and Pater (2000) independently contend that a voiceless stop in that position is indeed aspirated in American English, and again refers to Van Dam and Weaver's (2001) study considering the voice onset time of the voiceless stop at the beginning of the third syllable in the words Winnepegósis, Mèditerránean, and Nèbuchadnézzar. They found that these stops had an average voice onset time of more than 50 milliseconds, which is almost as aspirated as pretonic stops, and definitely more aspirated than voiceless stops at the beginning of stressless syllables immediately after the stressed syllable in words like múppets and móccasins, with very short voice onset times, less than 20 milliseconds on average for the non-coronal stops (the coronal flap is even briefer).

Expletive infixation, i.e., the infixation of an emphatic element like fuckin', frickin, bloody, bloomin', etc. (first described in Aronoff 1976) can also be used to detect foot boundaries. The generalization regarding expletive infixation is that the expletive occurs before the foot boundary, e.g. po-fuckin'-tato, Ne-fuckin'-braska. McCarthy (1982) observed that words like Winnepesáukee show variation with respect to this process: both Winne-frickin-pesaukee and Winnepe-frickin-saukee are possible, which suggests that both - pe- and -sau- are footheads. McCarthy's observation regarding the variant forms appears correct and robust, as Davis (2003) says, adding mili-fuckin'-taristic and milita-fuckin'-ristic. However, applied to càpitalístic, only the form capita-frickin-listic is judged to be acceptable, with the expletive after the foot-final third syllable. The form capi-frickin-talistic appears illicit, especially if the flapping of the $/ \mathrm{t} /$ of the original third syllable is maintained.

Notice that the data regarding expletive infixation is only relevant as an argument for the different footing of militarístic and càpitalistic, which Davis (2005) sees as a PU effect: like Steriade, he claims that the flap in càpitalístic can be accounted for by paradigm uniformity with cápital. However, unlike Steriade, he argues that the expected regular pattern is the one found in militaristic, that is, aspiration in the third syllable of a word-internal dactyl due to its foothead status, and it is càpitalístic that exhibits flapping because of uniformity of foot structure with cápital. This explains aspiration in underived words like Nàvratilóva, too, 
which was left unanalysed by Steriade. A weakness of Davis's (2005) treatment of foot structure and aspiration is illustrated in (13): in the representations taken from his paper, the superfoot is the same whether it is word-initial (as in potáto, see (13b)) or not (as in Wînnepesáukee, see (13a)), although undoubtedly aspiration is stronger word-initially.

\section{a. Wìnnepesáukee}

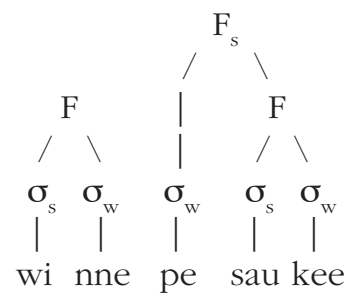

b. potáto

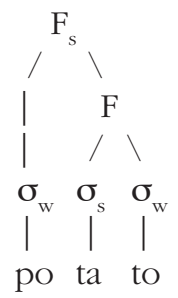

Of course, expletive infixation is unable to test the assumed asymmetrical behaviour of final and nonfinal dactyls, since infixation is not possible when no foot boundary follows, as in vánity. What remains as an argument for Davis is t-allophony, which is considerably weakened by the data cited in the preceding section, suggesting that there is not such an asymmetry. So much so that Anderson and Ewen (1987: 83) propose a similar superfoot-structure for words like héretic, arithmetic, where the underlined / $\mathrm{t} /$ is aspirated rather than tapped. Their figure 2.97 is reproduced below in (14). It shows that within trisyllabic feet like heretic, they assume that since metrical structure in English is binary, the stressed vowel (in be-) first forms a so-called subfoot (here-, indexed with 1), and then a superfoot (indexed with 2). The consonant immediately following the stressed vowel $(/ \mathrm{r} /)$ is foot-internal and therefore ambisyllabic (i.e., belongs to two syllables at the same time, that is why it is surrounded by brackets in (14)), whereas the next consonant $(/ \mathrm{t} /)$ is exclusively syllable-initial because it is shielded from becoming ambisyllabic by the bracket closing the subfoot.

$$
\text { (14) }{ }_{2}\left[{ }_{1}[[\text { he[r]e }]]_{1}[\text { tic }]\right]_{2}
$$

The basic difference between Davis' Winnepesaukee in (13a) and Anderson and Ewen's beretic in (14) is in the direction of adjunction for the formation of the superfoot. In this respect, Anderson and Ewen's model resembles van Oostendorp's analysis of Dutch fonologie in (8) above; in (15), similar representations are given corresponding to heretic (15a) and Winnepesaukee (15b). 
(15)
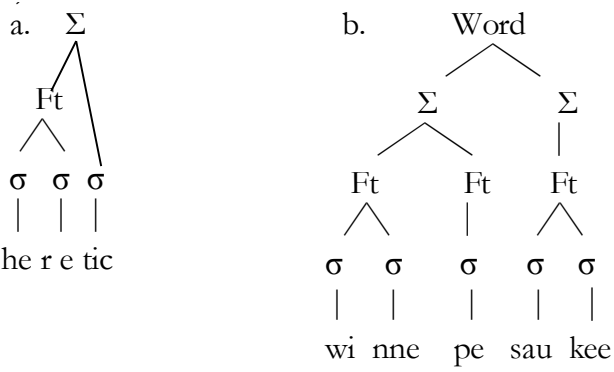

(15a) is the arboreal representation of (14), while (15b) is a total analogue to fonologie (8). In both, the third syllable of the dactyl is adjoined to the left; the difference is that in (15b) it forms a foot itself. This is due to the fact that Anderson and Ewen make use of the distinction between ambisyllabicity and absolute onsethood to derive the difference between the $/ \mathrm{r} /$ and the $/ \mathrm{t} /$, whereas to van Oostendorp this option is unavailable, all single intervocalic consonants being unambiguously parsed as onsets for him, he could only make pe stronger than nne by assigning it to a foot. This is the only way we can keep up the parallelism between final and nonfinal dactyls (viz., the third syllable is adjoined to the left) and make the /p/ in Winnepesáukee foot-initial (to account for its aspiration). The objection arises then, that if $p e$ is a foothead, which it is in (15b), how is it able to reduce its vowel to a schwa? This is not normally expected from footheads. Notice that the final syllable of béretic should retain its non-foothead status for the same reason: compare it to hésitàte, for example, whose final syllable must erect a foot and consequently its vowel cannot reduce, and the initial / $\mathrm{t} / \mathrm{of}$-tate is mandatorily aspirated and/or untapped. The vicious circle has closed: we are back with -pe- in Winnepesáukee adjoined to the left without projecting an intervening foot level complete analogy with (15a), i.e., no difference between final and nonfinal dactyls, but then why is that third syllable stronger than the second?

We conclude that a foot-based analysis is inadequate to account for the asymmetry between weak and semiweak positions on the one hand, and for the symmetry between final and nonfinal dactyls on the other. If one gets rid of ambisyllabicity as a theoretical device, neither possible adjunction analyses are fully satisfactory: they either predict the same amount of aspiration in Winnepesáukee as in potáto and/or hésitàte, or they allow for a reduced vowel in a monosyllabic foot. 


\section{WEAK AND SEMIWEAK POSITIONS IN VOWEL REDUCTION AND SCHWA SYNCOPE}

This section aims to provide an attempt at finding the English analogues of Dutch fonologie, that is, traces of the weak-semiweak distinction in vowel reduction (to schwa or zero). It is Burzio (1994: 113, footnote 14 - also cited in van Oostendorp 2000) who first pointed out that in English, foot-medial open syllables are affected by reduction to a greater extent than foot-final syllables. That is, for a word like Tàtamagóuchi, the pronunciation (toetoma)gouchi is preferable to (tatamo)gouchi, i.e., if one of the two unstressed vowels of the first foot (parenthesized) remains unreduced, it is more acceptable for the first (underlined) to reduce. The words (rigama)role, (panama) are claimed to behave analogously. This observation is totally analogous to the Dutch example in (7) above, and is straightforwardly interpretable as the tendency in semiweak position for vowels to be more resistant to reduction. Moreover, if pánama is analogous to Tàtamagóuchi, then this is additional evidence of the absence of asymmetry between word-internal and final dactyls, argued for in the previous section.

Burzio (ibid.) apparently finds a parallel situation as regards vowel syncope, that is, schwa-deletion: in mèmorizátion, so Burzio, the first foot contains two schwas in a row, out of which only the first can undergo syncope, i.e., (mem'ri) zation is a possibility, while *(memor')zation is not. Before arriving at too hasty conclusions, however, one must recognize that memorization is not the most fortunate example since, besides the well-known rarity of immediate pre-stress syncope in other than word-initial syllables, which renders the deletion of the schwa of -ri- (followed by primary-stressed $-z a$-) highly improbable, the segmental context $\left(r \_z\right)$ does not support its deletion, either.

To avoid such factors inhibiting vowel deletion, I carried out a survey with words like fúnctionary and nátionally, where a sequence of two unstressed (therefore syncopatable) vowels appears in the right segmental context (i.e.,

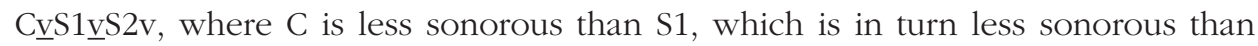
$\mathrm{S} 2 ; \mathrm{S}=$ sonorant consonant, and the third vowel is also unstressed). I used $\mathrm{EPD}^{5}$, LPD, and native informants to find out about the preferences of schwa deletion in such words. Unfortunately, there are not much more than 60 words that qualify for the present purposes, and this small number of examples is made even smaller by the fact that the majority of the sample consists of derived words, in the case of which Paradigm Uniformity (PU) effects can influence the choice of pronunciation. Also, the application of syncope is heavily influenced by word frequency (cf. Hooper 1978): less frequent words strongly resist it even if all the phonological

\footnotetext{
Thanks to Péter Szigetvári for making it available for online browsing.
} 
conditions are met, and natives are unable to judge nonsense words. Still, there remain a few examples in which the weak-semiweak distinction is able to manifest itself in spite of the morphological pressure, e.g. conféctionery and functionary

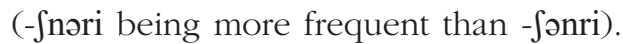

It is evident that schwa syncope in English is a complex phenomenon, influenced by a host of nonlinguistic or nonphonological factors. In addition, the quality, more specifically the sonority distance, of the consonants flanking the syncope site may affect a vowel's proneness to delete. Nevertheless, a generalization can be made to the effect that, in words of less transparent morphological structure at least, the weak-semiweak distinction seems to be justified.

\section{ANALYSIS}

It has been demonstrated above that previous foot-based accounts of the configurational aspect of lenition fail to properly describe the strong-weaksemiweak tripartite distinction. ${ }^{6}$ In what follows I present an alternative analysis, using the Strict CV framework as introduced in Section 1. I heavily rely on Ségéral and Scheer's (1999) and Szigetvári's (1999) definitions of government and licensing as two antagonistic forces. I claim that, crucially, it is not the third syllable of dactyls that is stronger than the second, it is the second that is weaker than the third. To explain this, I propose that once stress assignment designates a vowel to be (primary or secondary) stressed ${ }^{7}$, at least the following three features ensue: it (i) falls under the rubric of (4e) above ("Stressed vowels are unable to govern into non-peripheral units"); (ii) resists the Proper Government (PG) emanating from a following filled vowel, and instead (iii) distracts the licensing charge of the following vowel ${ }^{8}$. This results in grave consequences for the immediately following $\mathrm{CV}$-unit. On the one hand, the vowel there will never be able to properly govern another one, and therefore its PG will always hit its $\mathrm{C}$; on the other hand, the vowel's licensing is diverted from the $\mathrm{C}$ by the stressed nucleus: the consonant is expected to exhibit a strong tendency to undergo vocalic lenition. Meanwhile, the obligation to license the metrical head exhausts the vowel, so much that it becomes weaker, i.e., easier to reduce or delete. In contrast, later unstressed vowels are free to properly govern either their onsets or the preceding unstressed vowel (reducing it even further), and also to license their onsets. Therefore, such nuclei are stronger, and their onsets are both licensed and governed: these C's are

\footnotetext{
6 The nonconfigurational aspects are word frequency, PU, and the like.

7 A possible model of how that happens is sketched out in Szigetvári (1999) and Scheer (2004: 613ff).

8 V-to-V licensing has been proposed to be responsible for long vowels (Szigetvári 1999) or for vowel length alternations and to facilitate the survival of schwa (in French, at least) (Scheer 2004). The one sketched out here is yet another possibility, viz., that its target is dependent on stress relations.
} 
able to lenite, since they are governed, but they do so in such a way that licensing, supporting their melodic expression, reaches them as well.

In sum, the weak-semiweak distinction observed for consonants is due to the difference between the governed unlicensed and governed licensed position: the former is weaker than the latter. In the case of nuclei, on the other hand, the distinction results from the fact that the unstressed vowel immediately following the stressed one is forced to deplete its licensing potential via a marked relationship, $\mathrm{V}$-to-V licensing on the nuclear projection. The novelty of this analysis lies in its emphasis on the relative weakness of the weak position of the dactyl, rather than the relative strength of the semiweak position.

In (17), (18) and (19) below, a possible representation of governing and licensing interactions is sketched out. As I propose in (4f) that V-to-C government takes place between melodies, and it has long been believed that V-to-V relations are contracted on the nuclear projection, but $\mathrm{V}$ positions only have one shot of government and licensing each, which results in the complementary distribution of V-to-V government (i.e., PG) and V-to-C government on the one hand, V-to-C licensing and $\mathrm{V}$-to- $\mathrm{V}$ licensing on the other, it is apparent that this complex network of lateral relations existing on various levels of representation (i.e., tiers) can be best modelled in three dimensions. This is demonstrated by the representations of Italy /Irəli/ (17), ...petiti... (from competitive) $/ \mathrm{p}^{\mathrm{h}} \mathrm{er} \mathrm{t}^{\mathrm{h}} \mathrm{I} /$ (18) and Italy $/ \mathrm{It}^{\mathrm{t}}$ II/ (19). The upper level is the CV-tier (typed in grey): this is where skeletal positions communicate. The CV-tier itself is however made up of two tiers, the C-tier (where C positions are adjacent, in, e.g., consonant harmony systems) and the V-tier (the former "nuclear projection", where V positions interact, irrespective of the enclosed C's). The melodic tier (typed in black) is structured analogously: it is composed of vocalic melodies (along the broken line) and consonantal ones (along the dotted line). Government applies on either the V-tier or the melodic tier, whereas licensing is exclusive to the CV-tier. The skeletal positions are in cases other than floaters linked to their respective melodies by vertical association lines, as usual in autosegmental representations. These association lines are of utmost importance since they ensure that a skeletal slot and its melody are in fact one and the same object, together constituting the segment. Thus, PG is associated with the V-tier by definition, but the same governing relation may hit a consonant on the melodic tier (at the lower level) and effect lenition. Notice that all binary relations in such a model are strictly local, even PG. 
(17) Italy /'Irəli/

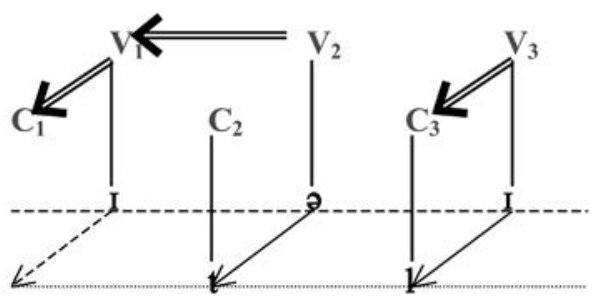

In Italy, when the second vowel $\left(\mathrm{V}_{2}\right)$ is not properly governed and is therefore pronounced, the final vowel $\left(\mathrm{V}_{3}\right)$ governs the melody of the preceding consonant (/l/) (single arrow), but it also licenses it (double arrow): the consonant finds itself in a governed licensed position, that is, it is semiweak. $\mathrm{C}_{2}$, however, is weak since it is governed only; $\mathrm{V}_{2}$ 's licensing is consumed by $\mathrm{V}_{1}$, the metrical head, which in turn licenses $\mathrm{C}_{1}$, and also attempts to govern it, but as it is empty, this government can only manifest itself in connected speech when the preceding word ends in a consonant, e.g., hate Italy (with the underlined /t/ potentially tapped).

Now consider the example of the strong-weak-semiweak distinction in tapping, the relevant portion of competitive $/ \mathrm{p}^{\mathrm{h}} \operatorname{er}^{\mathrm{h}} \mathrm{t} \mathrm{I}$ in (18). The $/ \mathrm{p} /$ is licensed only (and aspirated as a consequence), since stressed vowels cannot govern into nonperipheral units. This is a strong phonological position. $\mathrm{C}_{2}$, however, is weak, for the same reasons as the $/ \mathrm{t} /$ in Italy in (17), and $\mathrm{C}_{3}$ is semiweak because it receives both government and licensing: it is expected to vacillate between a tap, an unaspirated voiceless plosive, and an aspirated one.

(18) ...petiti... (from competitive) // $\mathrm{p}^{\mathrm{h}} \mathrm{erət}^{\mathrm{h}} \mathrm{I} /$

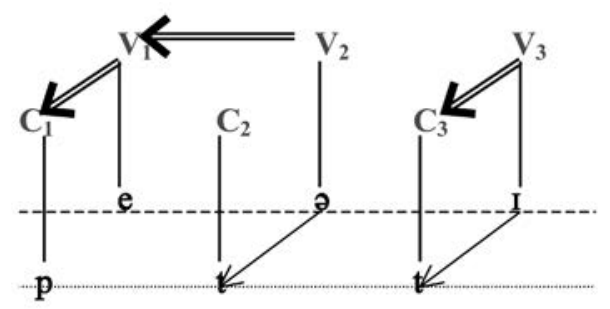

Finally, Italy /'It' $1 \mathrm{l} /$ illustrates PG (between $\mathrm{V}_{3}$ and $\mathrm{V}_{2}$ ), which results in the underparsing of $\mathrm{V}_{2}$ 's melody (indicated by the empty box). Governed vocalic positions are phonetically uninterpreted and are deprived of all their governing and licensing capacities. Therefore, $\mathrm{C}_{2}$ is ungoverned unlicensed, and as such is expected to lenite consonantally, i.e., undergo glottalisation. 
(19) Italy /' $\mathrm{It}^{\mathrm{P}} \mathrm{l} \mathrm{I} /$

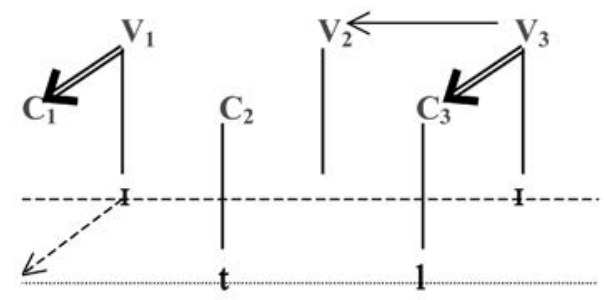

The advantage of this model over previous ones is that it does not only cover all the observations enumerated in the preceding sections, but it does so in such a way that it makes use of notions and principles (enumerated in (4) above) which have been independently motivated in the literature, and it conforms to the fundamental tenets of GP and CVCV phonology.

\section{CONCLUSION}

The paper makes two fundamental claims. On the one hand, it is extensively argued for that the distinction between weak and semiweak phonological positions seems to be justified in English, too, besides other Germanic languages like Dutch, which exhibit the same type of stress-sensitive pattern of lenition. On the other hand, it is shown what weaknesses earlier foot-based analyses suffer from, and how the CVCV framework, more specifically, the notion of government and licensing as two relations of opposing effect, is capable of expressing the tripartite distinction between strong (licensed ungoverned), weak (unlicensed governed) and semiweak (licensed governed) phonological positions. The fourth logical possibility, that of an unlicensed ungoverned position, is also weak but triggers lenition along a different trajectory.

This model also explains what happens in word-initial unstressed syllables, traditionally analysed as degenerate feet or as unstressed syllables adjoined to the right, e.g. in potato. Since such syllables display a hybrid-like behaviour, with a strong consonant but a weak vowel, neither of the two proposals describe them properly. In contrast, it falls out naturally from the present analysis that this is indeed the expected state of affairs: although the vowel is unstressed and therefore reduced, its licensing charge is not diverted from its onset consonant as there is no stressed vowel to the left; its government, however, avoids the $\mathrm{C}$ because the silencing of the boundary marker is of higher importance. Consequently, the /p/ of potato finds itself in a licensed ungoverned, i.e. strong, position in the same way as the pretonic $/ \mathrm{t} /$. 


\section{REFERENCES}

Anderson, J. and C. Ewen. 1987. Principles of Dependency Phonology. Cambridge: Cambridge University Press.

Aronoff, M. 1976. Word Formation in Generative Grammar. Cambridge, MA: MIT Press.

Burzio, L. 1994. Principles of English Stress. Cambridge: Cambridge University Press.

Davis, S. 2001. "On the analysis of aspirated weak syllables in English". Lecture given at Stanford University.

Davis, S. 2003. "The footing of dactylic sequences in American English". A New Century of Phonology and Phonological Theory. Eds. T. Homna, M. Okazaki, T. Tabata and S. Tanaka. Tokyo: Kaitakusha. 277-289.

Davis, S. 2005. "Capitalistic' vs. 'militaristic': The paradigm uniformity effect reconsidered". Paradigms in Phonological Theory. Eds. L. Downing, T. A. Hall and R. Raffelsieffen. Oxford: Oxford University Press. 107-121.

EPD = Searchable English Pronunciation Dictionary: http://seas3.elte.hu/epd.html

Harris, J. and J. Kaye. 1990. "A tale of two cities: London glottalling and New York City tapping". The Linguistic Review 7: 251-274.

Hayes, B. 1982. "Extrametricality and English stress". Linguistic Inquiry 13: 227276.

Hooper, J. B. 1978. "Constraints on schwa-deletion in American English". Recent Developments in Historical Phonology. Ed. J. Fisiak. Berlin/New York: Mouton de Gruyter. 183-207.

Jensen, J. T. 1987. "English stop allophones in metrical theory". Proceedings of the XIth International Congress of Phonetic Sciences, Volume 2. 153-156.

Jensen, J. T. 2000. "Against ambisyllabicity". Phonology 17.2: 187-235.

Kahn, D. 1976/1980. Syllable-Based Generalizations in English Phonology. MIT dissertation published by New York and London: Garland Publishing Inc.

Kaye, J., J. Lowenstamm and J.-R. Vergnaud. 1985. "The internal structure of phonological representations: a theory of charm and government". Phonology Yearbook 2: 305-328.

Kaye, J., J. Lowenstamm and J.-R. Vergnaud. 1990. "Constituent structure and government in phonology". Phonology 7: 193-231.

Kenstowicz, M. 1994. Phonology in Generative Grammar. Cambridge, Mass. and Oxford: Blackwell. 
Kreidler, Ch. 1989. The Pronunciation of English. Cambridge, Mass. and Oxford: Blackwell.

Lowenstamm, J. 1996. "CV as the only syllable type". Current Trends in Phonology: Models and Methods. Eds. J. Durand and B. Laks. European Studies Research Institute, University of Salford Publications. 419-442.

Lowenstamm, J. 1999. "The beginning of the word". Phonologica 1996. Syllables!? Eds. Rennison, J. and K. Kühnhammer. The Hague: Holland Academic Graphics. 153-166.

LPD = Wells, J. C., ed. 1990. Longman Pronunciation Dictionary. London: Longman.

McCarthy, J. J. 1982. "Prosodic structure and expletive infixation". Language 58: 574-590.

Pater, J. 2000. "Nonuniformity in English stress: the role of ranked and lexically specific constraints". Phonology 17.2: 237-274.

Patterson, D. and C. M. Connine. 2001. "Variant frequency in flap production. A corpus analysis of variant frequency in American English flap production". Phonetica 2001; 58: 254-275.

Scheer, T. 2004. A Lateral Theory of Phonology. Vol 1: What is CVCV, and Why Should it Be? Berlin: Mouton de Gruyter.

Ségéral, P. and T. Scheer. 1999. "The Coda Mirror". Ms.: Université de Paris 7 and Université de Nice.

Selkirk, E. O. 1982. (written in 1978) "The syllable". The Structure of Phonological Representations, Part II. Eds. H. van der Hulst and N. Smith. Dordrecht: Foris Publications. 337-383.

Steriade, D. 2000. "Paradigm uniformity and the phonetics-phonology boundary". Papers in Laboratory Phonology. Vol.5. Eds. J. Pierrehumbert and M. Broe. Cambridge: Cambridge University Press. 313-334.

Szigetvári, P. 1999. VC Phonology: A Theory of Consonant Lenition and Phonotactics. Unpublished PhD dissertation. MTA/ELTE, Budapest: Hungary.

Vaux, B. 2002. "Aspiration in English". Ms.: Harvard University.

Van Dam, M. and P. Weaver. 2001. "Aspiration of stressless intervocalic voiceless stops in English". Ms. Indiana University: Bloomington.

Van Oostendorp, M. 2000. Phonological Projection. A Theory of Feature Content and Prosodic Structure. Berlin and New York: Mouton de Gruyter.

Withgott, M. M. 1982. Segmental Evidence for Phonological Constituents. Unpublished PhD dissertation. University of Texas, Austin: USA. 